\title{
Monoacylglycerol Lipase ABHD12
}

National Cancer Institute

\section{Source}

National Cancer Institute. Monoacylglycerol Lipase ABHD12. NCI Thesaurus. Code

C118547.

Monoacylglycerol lipase ABHD12 (398 aa, $\sim 45 \mathrm{kDa}$ ) is encoded by the human ABHD12 gene. This protein plays a role in endocannabinoid hydrolysis. 